\title{
Device-associated Infections in a Colombian Neonatal Intensive Care Unit
}

\section{Infecciones nosocomiales asociadas a dispositivos médicos en una unidad de cuidado intensivo neonatal en Colombia}

\author{
Germán A. Contreras-Cuellar ${ }^{1}$, Aura L. Leal-Castro ${ }^{1,2,}$ Reinaldo Prieto ${ }^{2}$ and \\ Alba L. Carvajal-Hermida ${ }^{2}$ \\ 1 Microbiology Department, Medicine Faculty, Universidad Nacional de Colombia. Bogotá \\ gacontrerasc@unal.edu.co; allealc@unal.edu.co \\ 2 Epidemiology Unit, Unidad de Pediatría, Clínica San Pedro Claver, Bogotá, Colombia \\ Received $21^{\text {th }}$ November 2006/Sent for Modification $26^{\text {th }}$ Jun 2007/Accepted $10^{\text {th }}$ August 2007
}

\section{ABSTRACT}

Objective The present study was aimed at determining device-associated infection rates, device use rates and the microbiologic profile of nosocomial infections in a tertiary neonatal intensive care unit (ICU) in Bogotá, Colombia.

Methods Prospective nosocomial infection surveillance was implemented in a neonatal intensive care unit for 11 months in line with the High Risk Nursery component of the Colombian Nosocomial Infection Surveillance programme. Patientdays, length of stay, device use rates and device-associated nosocomial infection rates were calculated.

Results 1998 device days were observed among 2890 patient days during the 11 months' surveillance. Central venous catheter-related bloodstream infection was the most common device-associated infection for all birth-weight categories. 69,2\% and $100 \%$ of all coagulase negative staphylococci and Staphylococcus aureus infections were methicillin resistant strains and all gram negative rods were susceptible to third generation cephalosporins, carbapenems, ciprofloxacin and piperacillin-tazobactam. Device-associated infection and device use rates in the ICU were higher than Colombian Nosocomial Infection Surveillance reports for October 2004 and reports from Colombia and other Latin-American countries.

Conclusions This surveillance identified blood-stream infection as being the most common infection in the ICU in question. Efforts should thus be directed at establishing suitable infection-control practices.

Key Words: Intensive care unit, neonate, cross-infection, Colombia (source: $\mathrm{MeSH}$, $N L M)$.

\section{RESUMEN}

Objetivo El objetivo del presente estudio fue determinar las tasas de infección asociadas a dispositivos médicos, las tasas de utilización y el perfil microbiológico 
de las infecciones hospitalarias en una unidad de terapia intensiva neonatal en Bogotá-Colombia.

Métodos Un sistema de vigilancia de infección hospitalaria fue implementado en la unidad de terapia intensiva neonatal de un hospital de tercer nivel durante un periodo de 11 meses de acuerdo al componente neonatal del sistema de vigilancia de infección hospitalaria de los estados unidos. Se calcularon los días pacientes, los días de estancia, las tasas de utilización y de infección asociadas a dispositivos invasivos.

Resultados Un total de 1998 días dispositivos fueron observados entre 2890 días paciente durante los 11 meses de vigilancia. La infección asociada a catéter central fue la infección más frecuente entre las diferentes categorías de peso neonatal. El $69,2 \%$ y el $100 \%$ de todos los Staphylococos coagulasa negativa y Staphylococcus aureus fueron resistentes a meticilina respectivamente, y todos los bacilos gram negativos fueron susceptibles a las Cefalosporinas de tercera generación, Carbapenemicos, Ciprofloxacina y a Piperacilina-Tazobactam. Las tasas de infección asociada a dispositivos invasivos y las tasas de utilización en nuestra unidad fueron superiores al reporte de octubre del 2004 del sistema de vigilancia de infección hospitalaria de los estados unidos y de otros trabajos realizados en Colombia y en Latinoamérica.

Conclusiones Este proceso de vigilancia ha permitido identificar que las infecciones del torrente sanguíneo comprende el principal problema de nuestra unidad y por tal motivo la necesidad de implementar adecuadas medidas de control de infecciones para disminuir la ocurrencia de esta infección debe ser la prioridad de nuestra institución.

Palabras Clave: Unidades de terapia intensiva, Infección hospitalaria, Colombia (fuente: DeCS, BIREME).

$\mathrm{N}$ osocomial infection (NI) is the most commonly found complication in a hospital setting. The morbidity and mortality related to such complications are substantially higher when compared to other medical complications (1).

The new-born represent one of the most vulnerable populations amongst the paediatric group, especially neonates hospitalised in a neonatal intensive care unit (NICU) where large-scale use medical devices, antimicrobial drugs and lack of maturation of a child's immune system increase the chances of acquiring an NI (2). NI incidence rate in Colombia is 6,2 per 1000 patients, BSI being the most common NI (3). NI incidence rate tends to be greater in developing countries such as Brazil and Taiwan $(4,5)$.

Standard infection control (IC) programmes and device-associated infection (DAI) rates for NICU are limited in developing countries, although several 
studies have shown that NI programmes (including surveillance), infection rate feedback and education have resulted in a significant impact on the occurrence of this type of complication (6,7). Creating surveillance systems and producing data related to NI and DAI rates in a specific country would help institutions to compare and share their experience. It would also help in formulating control policy. This study was thus aimed at determining device-associated (DA) NI rates in a Colombian tertiary public hospital's NICU.

\section{MATERIALS AND METHODS}

Patients and setting

The San Pedro Claver Hospital is a public, teaching hospital and tertiary care centre in Bogotá, Colombia. The NICU consists of two rooms; the first includes 15 beds for neonatal medical care and the second is where infected neonates are hospitalised. The NICU staff consists of three assistant nurses, one chief nurse and one paediatrician. Consultancy is available for nutrition, radiology and physiotherapy services. The nurse to patient ratio is generally 1:5.

\section{Infection control practice}

The NICU has bactericidal soap and alcohol-based hand washing and cleaning protocols. Guidelines have been established for performing invasive procedures, such as placing intravenous catheters and mechanical ventilation. However, guidelines for managing and monitoring medical devices are not available at the unit. A single nurse carried out NI surveillance in the NICU. NI case data is collected daily for the programme but information regarding medical devices has not been collected since the programme began.

\section{Study design}

Prospective NI surveillance was implemented in the NICU for 11 months from February to December 2005, according to the NNIS High Risk Nursery component (8). Surveillance started after a one-month trial where the infection control practitioner (ICP) was trained in collecting data and becoming familiar with NI definitions. Neonates were monitored daily for NI at all body sites. If a patient developed a NI then the ICP recorded such information on a standardised worksheet including data regarding identification, admission diagnosis, type of delivery, birth-weight category ( $\leq 1,000$ grams, $1,001-1,500$ grams, 1,501-2,500 grams and >2,500 grams), gestational age, medical devices used, antibiotics used and microbiologic information. Each neonate recorded as having an NI was discussed each month by the paediatrician and the IC team. 
Definitions of NI

Centers for Disease Control and Prevention criteria were used as standard definitions for NIs (9). Infections were regarded as being nosocomial if they occurred 48 hours after being admitted to hospital and presented clinical signs or symptoms suggestive of infection. All neonates were followed-up for infection for the 48 hours following being transferred from the NICU to another hospital ward.

Laboratory-confirmed blood stream infection

The definition of primary blood stream infection (BSI) includes both clinical sepsis and laboratory-confirmed BSI. Infection was classified as being secondary BSI when a patient had a culture-confirmed BSI and a related NI at another site. An exception was when an intravascular device was present and no other infection site was evidenced which was classified as primary. One or more blood cultures for a recognised pathogen were considered significant and two or more blood cultures were considered significant for common skin contaminants.

Clinical sepsis

This was defined as being the presence of at least one of the following criteria having no other recognised cause: fever $\left(>38^{\circ} \mathrm{C}\right)$, hypothermia $\left(<37^{\circ} \mathrm{C}\right)$, apnoea or bradycardia and no blood culture being performed. The paediatrician initiated treatment for sepsis if one of the foregoing was found and no organisms were detected in blood cultures.

Pneumonia

A newborn received a diagnosis of pneumonia if at least two of the following signs or symptoms were present: apnoea, tachypnea and bradycardia. At least one of the following was also necessary: increased production of respiratory secretions or increased suctioning requirements, isolation of an aetiological agent from a specimen obtained by transtracheal aspirate and two or more serial chest radiographs showing new or progressive infiltrate, cavitation and/ or consolidation.

Mortality

Mortality included all deaths occurring in the NICU or within $48 \mathrm{~h}$ after discharge or transfer to other hospital wards. It was calculated as being the number of deaths secondary to NI divided by the total number of neonates during the study period then multiplied by 1,000. 
Statistical analysis

Data was entered and analysed with Epi Info 6.04. Patient-days, length of stay, device-use rates and DA NI rates were calculated according to NNIS methodology (8). Central line rates (umbilical lines and peripherally-inserted central line), ventilator use and DA rates were compared to the high risk nursery surveillance component of the NNIS annual report dated October 2004 (10). $\mathrm{NI}$ incidence density rate was calculated as being the number of $\mathrm{NI} /$ patient days, and then multiplied by 1000 .

\section{RESULTS}

Demographic characteristics

289 neonates were included during the study period. Gestational age distribution was $8,3 \%(\mathrm{n}=24)$ for $<28$ weeks, $14,2 \%(\mathrm{n}=41)$ for $29-32$ weeks, 39,8 \% $(\mathrm{n}=115)$ for $33-36$ weeks and 37,7 \% ( $\mathrm{n}=109)$ for $>36$ weeks. 45,7 \% ( $=134)$ of the population had 1500 -2 500 grams birth-weight. Gender distribution was $44,3 \%(n=128)$ female and 55,7 \% ( $\mathrm{n}=161)$ male.

\section{NI characteristics}

Forty-two neonates had 44 documented NI. Two (4,7 \%) suffered 2 episodes and $40(95,2 \%)$ only one episode. $50 \%$ of infected patients had a gestational age of less than 28 weeks and 43,2 \% had 1 000-1 500 grams birth-weight. NI incidence density rate was 15,2 per 1000 patient-days.

NI distribution and mortality rate associated with nosocomial infection The most frequent types of NI were BSI (72,7 \%), followed by pneumonia $(18,2 \%)$, necrotising enterocolitis $(6,8 \%)$ and meningitis (2,3\%). BSI and pneumonia rates were 11 per 1000 patient-days and 2,7 per 1000 patientdays, respectively. BSI and pneumonia rates stratified by birth-weight are shown in Table 1.

Table 1. BSI and pneumonia incidence rates by birth-weight category

\begin{tabular}{cccccc}
\hline Birth-weight & $\begin{array}{c}\mathrm{N}^{\circ} \text { of patients } \\
\text { during the } \\
\text { study period }\end{array}$ & $\begin{array}{c}\mathrm{N}^{\circ} \text { of } \\
\mathrm{BSI}\end{array}$ & $\begin{array}{c}\mathrm{BSI} / 1,000 \\
\text { patients- } \\
\text { days }{ }^{\mathrm{a}}\end{array}$ & $\begin{array}{c}\mathrm{N}^{\circ} \text { of } \\
\text { pneumonia }\end{array}$ & $\begin{array}{c}\text { Pneumonia/1,000 } \\
\text { patient-days }\end{array}$ \\
\hline$\leq 1,000 \mathrm{~g}$ & 19 & 3 & 7,6 & 4 & 10,2 \\
$1,001-1,500 \mathrm{~g}$ & 36 & 13 & 15,2 & 4 & 4,6 \\
$1,501-2,500$ & 132 & 12 & 10,5 & 0 & 0 \\
$>2,500$ & 102 & 4 & 7,9 & 0 & 0 \\
\hline BSI= Blood stream infection. ${ }^{\mathrm{a}}$ Number of BSI/patient days then multiplied by $1,000 .{ }^{6}$ Number of
\end{tabular}

pneumonias/patient days, then multiplied by 1,000 . 
DAI and medical device use rates 1998 device days were observed among 2890 patient days during the 11 months' surveillance. There were 1701 device-days for individual central line devices and 297 for mechanical ventilators. 23 out of 32 (71,8 \%) episodes of BSI were related to central vascular catheters. 4 out of 8 (50 \%) pneumonias occurred in neonates who were mechanically ventilated. Device use and DAI are shown in Table 2.

\begin{tabular}{|c|c|c|c|c|c|}
\hline Birth-weight & $\begin{array}{l}\text { Patient- } \\
\text { days }\end{array}$ & $\begin{array}{c}\text { Central } \\
\text { line days }\end{array}$ & $\begin{array}{c}\text { Central line } \\
\text { associated } \\
\text { BSI }\end{array}$ & $\begin{array}{c}\text { Central line use } \\
\text { rate }^{\text {a }}\end{array}$ & $\begin{array}{c}\text { Central line } \\
\text { associated BSI } \\
\text { rate }^{\mathrm{D}}\end{array}$ \\
\hline$\leq 1000 \mathrm{~g}$ & 393 & 311 & 3 & 0,79 & 9,6 \\
\hline $1001-1500$ & 855 & 767 & 11 & 0.89 & 14.3 \\
\hline $1501-2500$ & 1139 & 505 & 7 & 0,44 & 13,8 \\
\hline$>2500$ & 503 & 118 & 2 & 0,23 & 16,9 \\
\hline Birth-weight & $\begin{array}{l}\text { Patient- } \\
\text { days }\end{array}$ & $\begin{array}{c}\text { Ventilator } \\
\text { days }\end{array}$ & $\begin{array}{c}\text { Ventilator } \\
\text { associated } \\
\text { pneumonia }\end{array}$ & $\begin{array}{c}\text { Ventilator use } \\
\text { rate }^{\text {a }}\end{array}$ & $\begin{array}{c}\text { Ventilator } \\
\text { associated } \\
\text { pneumonia rate }^{\text {b }}\end{array}$ \\
\hline$\leq 1000 \mathrm{~g}$ & 393 & 98 & 2 & 0,24 & 20,4 \\
\hline $1001-1500$ & 855 & 109 & 2 & 0,12 & 18,3 \\
\hline $1501-2500$ & 988 & 66 & 0 & 0,06 & 0 \\
\hline$>2500$ & 503 & 24 & 0 & 0,04 & 0 \\
\hline
\end{tabular}

Pathogen distribution amongst NI and mortality rate

The most common micro-organisms isolated were Gram-positive bacteria (60 $\%)$, followed by Gram-negative bacteria (36,3 \%) and fungi (3,03 \%). 69,2 \% of coagulase-negative staphylococci (CoNS) and $100 \%$ of Staphylococcus aureus were resistant to methicillin and all staphylococci and enterococci were susceptible to vancomycin. Enterobactereciae were susceptible to thirdgeneration cephalosporins, carbapenems, ciprofloxacin and piperacillintazobactam. Acinetobacter baumannii was susceptible to all the antibiotics tested. Pathogen distribution differed according to the type of NI; (CoNS) (52 $\%$ ) were the most common in bacteraemia and S. aureus (60 \%) in pneumonia. BSI and pneumonia were $21,8 \%$ and $37,5 \%$ culture-negative, respectively. NI patient mortality rate was 3,4 per 1000 patients.

\section{DISCUSSION}

Overall NI incidence in the NICU in question was considerably higher than the previous report in our country and other rates in the USA $(3,11)$, but lower than rates reported in a Brazilian and a Dutch study $(12,13)$. Such differences between our rate and the overall NI rates published in the literature should be taken with caution, given that there are significant differences in characteristics 
regarding the hospital, the newlyborn, the methods and the definitions for NI surveillance in the neonatal care units, and the size of the denominators. If infection rates are going to be compared between studies, then they must be adjusted for patients' infection risk and have sample size denominators.

Bacteraemia and pneumonia are the most common NI in neonates (14). The highest rates of BSI and pneumonia are reported in neonates having $<1,000$ grams birth-weight. However, we founded the highest BSI rates in the 1000 1500 grams and 1501-2 500 grams birth-weight categories. This result can be explained by considering the higher proportion of neonates having 1 000-1 501 grams birth-weight in our unit. By contrast, pneumonia rates were highest in neonates having $<1000$ grams birth-weight. This was consistent with the risk represented by extremely low birth-weight in the development of infection. There is a $3 \%$ increase in the risk of NI for every 500 grams decrease in birthweight and the probability of infection is 2,2 times greater in neonates having $\leq$ 1000 gm birth-weight (15).

Our local use and infection rates for mechanical ventilators and central venous lines were higher when compared to NNIS data. This can be explained by practitioners, chief nurses, assistant nurses and physiotherapists' lack of knowledge concerning published IC guidelines. There is also a lack of awareness regarding institutional rates of infection. Our unit's nurse-patient ratio is lower than NICU in the USA. The risk of infection related to medical devices increases significantly when NICU have a lower nurse to patient ratio and are staffed by inexperienced nurses (16).

CoNS were the most frequent isolated organisms, accounting for $52 \%$ of our bloodstream isolates, and appeared to be related to intravascular device use. However, CoNS' role as a true pathogen is still being debated. Identifying and treating CoNS as a probable causative agent of infection must thus be based on the neonates' clinical condition. The high methicillin resistance levels founded among CoNS isolated from NIs support the findings from previous works where resistance to $\beta$-lactam antibiotics in CoNS was high (18). $100 \%$ of CoNS were susceptible to vancomycin. However, a recent group of articles has reported increased vancomycin MIC for clinical CoNS (17).

The most common causes of death in neonates lies in infection and currently causes about 1600000 deaths per year in developing countries (18). We only had one episode of NI-related mortality in our study, occurring in a neonate having $\leq 1000$ grams birth-weight, infection being caused by a gram- 
negative organism. However, we cannot assume that gram-positive organism infections (especially CoNS) have a better outcome than gram-negative ones because most isolates in our unit came from neonates having birth-weight greater than 1500 grams and the probability of a poor outcome in neonates having CoNS or a less virulent organism increases when patients have a lower birth-weight.

This study had its limitations. Firstly, this study was carried out at a single tertiary care centre, so the results from this study may not apply to other institutions. Secondly, the denominators for the rates were smaller when compared to NNIS denominators. Thirdly, a severity of illness score was not recorded in our data; this could have helped to provided additional information related to a prognosis of NI. Fourthly, the real impact of antimicrobial resistance amongst gram-negatives is not really known, given the low number of gram-negative isolates in our study.

NI surveillance has thus become a necessary tool for reducing the risk of NI in developing countries. The method to be chosen depends on particular goals and available resources. Regardless of the limitations, this surveillance has served to identify local problems and will help in defining our unit's priorities and encourage other institutions to institute surveillance systems in NICU in Colombia. It is hoped that knowledge of this epidemiological pattern in our institution will provide the strength for changing current practice and accepting IC practice

\section{REFERENCES}

1. Hedrick TL, Sawyer RG. Health-care-associated infections and prevention. Surg Clin North Am. 2005;85:1137-52.

2. Brady MT. Health care-associated infections in the neonatal intensive care unit. Am J Infect Control. 2005;33:268-75.

3.Efird MM, Rojas MA, Lozano JM, Bose CL, Rojas MX, Rondon MA. Epidemiology of nosocomial infections in selected neonatal intensive care units in Colombia, South America. J Perinatol. 2005;25:531-6.

4.Couto RC, Carvalho EA, Pedrosa TM, Pedroso ER, Neto MC, Biscione FM. A 10year prospective surveillance of nosocomial infections in neonatal intensive care units. Am J Infect Control. 2007;35:183-9.

5. Su BH, Hsieh HY, Chiu HY, Lin HC, Lin HC. Nosocomial infection in a neonatal intensive care unit: a prospective study in Taiwan. Am J Infect Control. 2007;35:190-5. 
6. Rosenthal VD, Guzman S, Pezzotto SM, Crnich CJ. Effect of an infection control program using education and performance feedback on rates of intravascular device-associated bloodstream infections in intensive care units in Argentina. Am J Infect Control 2003;31:405-9.

7. Rosenthal VD, Guzman S, Crnich C. Impact of an infection control program on rates of ventilator-associated pneumonia in intensive care units in 2 Argentinean hospitals. Am J Infect Control. 2006;34:58-63.

8. NNIS Manual. US Department of Health and Human Services, Public Health Service, Centers for Disease Control and Prevention. May 1999; V-1.

9. Garner JS, Jarvis WR, Emori TG Horan TC, Hughes JM. CDC definitions for nosocomial infections. Am J Infect Control 1988;16:128-140.

10. Centers for Disease Control and Prevention. National Nosocomial Infections Surveillance (NNIS) system report, data summary from January 1992 through June 2004, Issued October 2004. Am J Infect Control 2004;32:470-85.

11. Stoll BJ, Hansen N, Fanaroff AA, Wright LL, Carlo WA, Ehrenkranz RA et al. Lateonset sepsis in very low birth-weight neonates: the experience of the NICHD Neonatal Research Network. Pediatrics. 2002;2:285-91.

12. Nagata E, Brito AS, Matsuo T. Nosocomial infections in a neonatal intensive care unit: Incidence and risk factors. Am J Infect Control 2002; 30:26-31.

13. Van der Zwet WC, Kaiser AM, van Elburg RM, Berkhof J, Fetter WP, Parlevliet GA et al. Nosocomial infections in a Dutch neonatal intensive care unit: surveillance study with definitions for infection specifically adapted for neonates. J Hosp Infect. 2005;61:300-11.

14. Urrea M, Iriondo M, Thio M, Krauel X, Serra M, LaTorre C, et al. A prospective incidence study of nosocomial infections in a neonatal care unit. Am J Infect Control. 2003;31:505-507.

15. Richards MJ, Edwards JR, Culver DH, Gaynes RP. Nosocomial infectionsin pediatric intensive care units in the United States. Pediatrics 1999;103:39-45.

16. Robert J, Fridkin SK, Blumberg HM, Anderson B, White N, Ray SM et al. The influence of the composition of the nursing staff on primary bloodstream infection rates in a surgical intensive care unit. Infect Control Hosp Epidemiol 2000; 21:12-1.

17. Center KJ, Reboli AC, Hubler R, Rodgers GL, Long SS. Decreased vancomycin susceptibility of coagulase-negative staphylococci in a neonatal intensive care unit: evidence of spread of Staphylococcus warneri.J Clin Microbiol. 2003;41:4660-5.

18. Vergnano S, Sharland M, Kazembe P, Mwansambo C, Heath PT. Neonatal sepsis: an international perspective. Arch Dis Child Fetal Neonatal 2005;90:F220-4. 